\title{
ENTREPRENE URSHIP TRAINING FOR YOUNG PEOPLE: IMPLICATIONS FROM USER NEEDS ANALYSIS FOR E- LEARNING PLATFORM YEU
}

\author{
Uğur T. KAPLANCALI* \\ Murat YÜCELEN**
}

\section{Abstract}

Long-term unemployment doubled in Europe between 2007-14 despite the recent recovery which is slowly translating into more jobs. The effects are felt severely by youth; the longer they remain unemployed, the more difficult it is for them to get hired again. As a method to cope with youth unemployment, the EU 's Leonardo Programme has been funding projects intended to enhance the entrepreneurship skills of young people. YENTELS (Young European Entrepreneurs E-Learning Suite) and YEU (Youth Enterprise and U nemployment) projects are examples of such platforms that provide online resources for enterprising. The e-learning platform, including a serious game, developed during YEU project paid close attention to young people who are not employed, in education or training. This study aims to report the process and results of the user needs analysis conducted for the YEU e-learning platform in order to tackle the issue of youth unemployment by incorporating the viewpoints and needs of multiple stakeholders in the context of entrepreneurship. By means of primary and secondary research methods, feedback was obtained from a total of approximately 40 stakeholders and 900 young people across Europe. A range of quantitative and qualitative research findings were identified in the areas of youth unemployment, entrepreneurship skills and policy making, with general observations and experiences also recorded by the project partners from seven countries. The conclusions of the analysis present valuable implications in the areas of E uropean policies, young

* Asst. Prof. Dr., Y editepe University, Faculty of Commerce, e-mail:
ugur.kaplancali@yeditepe.edu.tr
A sst. Prof. Dr., Y editepe University, Faculty of Commerce, e-mail: muratyucelen@gmail.com 
people's employment, and business start-up issues. The study also provides recommendations at a general level to improve the employability of young people.

Keywords: EU youth unemployment, entrepreneurship, e-learning, user needs analysis, serious games.

\section{GENÇ NÜFUSA YÖNELİK GİRIŞSiMC İLİK EĞITIMIM İ: YEU e- ÖĞRENME PLATFORMU KULLANICI İHTIYAÇLARI ANALIZIININ ETKİLERI}

\section{$\ddot{O} z$}

Yeni toparlanmaya başlayan AB ekonomisi yavaş da olsa iş imkanları yaratırken Avrupa'da 2007-14 arasında uzun vadeli işsizlik iki katına çıktı. Bunun etkilerini en ă̆ır şekilde gençler yaşamakta, ne kadar uzun süre işsiz kalırlarsa tekrar iş bulmaları o kadar zor olmaktadır. AB'nin Leonardo Programı genç işsizliği ile başa çıkabilmek için genç insanların girişimcilik becerilerini artırmaya yönelik projeleri fonlamaktadır. YENTELS ve YEU projeleri girişimciliğe yönelik çevrimiçi kaynaklar sunan platfomlara örnek teşkil etmektedir. YEU projesi sırasında geliştirilen e-ögrenme platform, bir ciddi oyun desteğiyle, özellikle işsiz, ögrenim veya mesleki eğitim safhasında olmayan gençleri yakından dikkate almaktadır. Bu çalışmanın amacı, YEU eögrenme platform için gerçekleştirilen kullanıcı ihtiyaçları analizi süreci ve sonuçlarını temel alınarak, girişimcilik becerileri kazanımı ile genç işsizliği sorunsalına ilgili paydaşların katkısı ile kapsamlı çözüm önerileri sunmaktır. Çalışmada birincil ve ikincil araştırma yöntemleri kullanılmış ve toplamda Avrupa genelinde yaklaşık 40 paydaş ve 900 gençten geri bildirim elde edilmiştir. Yedi ülkeden proje ortakları tarafindan kaydedilen genel gözlemler ve araştırma deneyimlerine dayanarak gençlerin istihdamı ve iş kurma seçenekleri alanlarında nicel ve nitel bulgular tespit edilmiştir. Sonuç olarak, $A B$ politikaları, gençlerin istihdamı ve kurulum aşamasındaki girişimler konularına ilişkin sonuçlar paylaşılmıştır. Çalışma ayrıca gençlerin istihdam edilebilirliklerini artırmaya katkıda bulunmak üzere genel düzeyde öneriler sunmaktadır.

Anahtar kelimeler: AB' de genç işsizlik, girişimcilik, e-öğrenme, kullanıcı ihtiyaçları analizi, ciddi oyunlar. 


\section{Introduction and Preamble}

A ccording to Eurostat's A pril 2016 figures, 21.224 million men and women in the EU-28 were unemployed, out of which 4.235 million were young people. $Y$ outh unemployment rate is the ratio of unemployed people aged 15-24 to the whole youth labor force. In A pril 2016, youth unemployment rate was $18.8 \%$ in the EU-28 and $21.1 \%$ in the Eurozone. Y outh unemployment has been around twice the general unemployment rate in the EU for more than a decade. Y outh unemployment rate in the EU averaged 19.53\% from 2000 until 2015, reaching an all-time high of $24 \%$ in January of 2013 and a record low of $15.20 \%$ in J anuary of 2008.

The economic crisis severely hit the young. With millions of young people in Europe constantly struggling to find a job, the economic recession has forced many to accept unpaid internships or become long-term unemployed - which leads to a lack of confidence, social exclusion, poorer health, and even depression.

From the second quarter of 2008, the EU's youth unemployment rate has taken an upward trend peaking in 2013 , before receding to $21.4 \%$ at the end of 2014. A ccording to the European Commission, more than 7 million Europeans in the 15-24 age group are not employed, in education or training (also known as "NEET" as seen in Figure 1 below).? For some of the Eurozone members' youth unemployment rates were drastically higher in 2013, with Greece over $59 \%$, Spain $57.4 \%$, Croatia $51.6 \%$, and Italy $41.2 \%$ where Prime M inister Enrico Letta said "Y outh unemployment is the true nightmare of our country," and warned of the risk of a "lost generation" (Gosh, 2013). 
Figure 1: N ot in Education, Employment or Training (NEET) \%

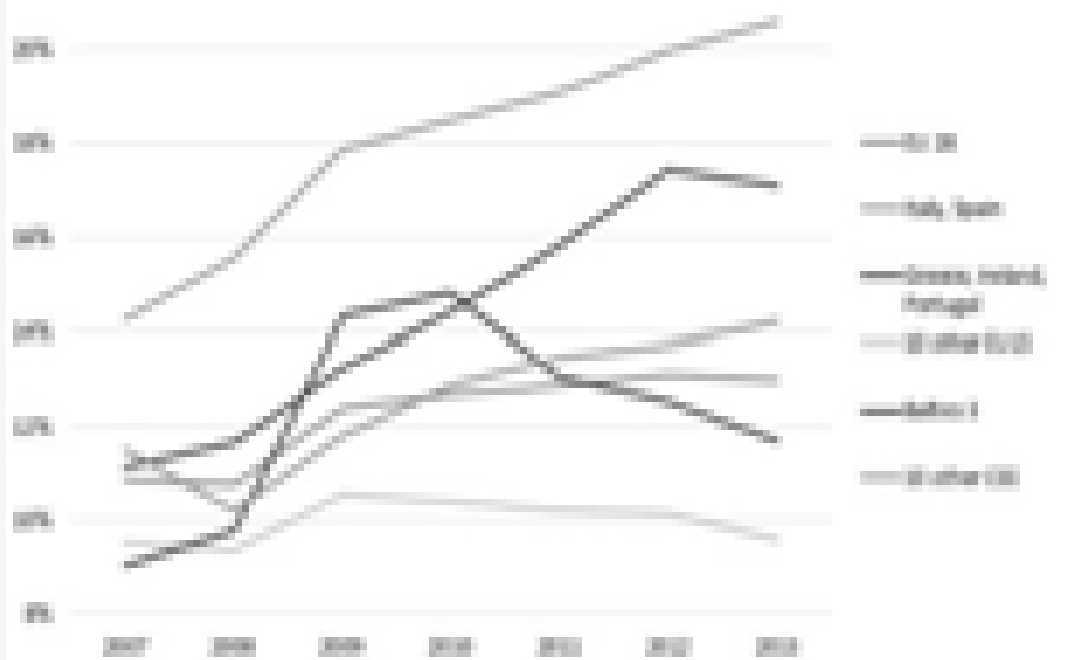

Source: Eurostat and Bruegel calculations. Country groups: 10 other EU15: Austria, Belgium, Denmark, Finland, France, Germany, Luxembourg, Netherlands, Sweden and U nited Kingdom; Baltics 3: Latvia, Lithuania, Estonia; 10 other CEE refers to the 10 member states that joined in the last decade, excluding the Baltics: Bulgaria Czech Republic, Croatia, Hungary, Poland, Romania, Slovenia, Slovakia, Cyprus and Malta; Sweden.

Higher youth unemployment rate is taking a toll not only on the youth of Europe but also on the European economy. A report by the European F oundation for the Improvement of Living and Working Conditions (Eurofound, 2015), a tripartite body of the Union, released the numbers on how much NEETs cost to their respective countries. The NEET costs to the $21 \mathrm{EU}$ countries included in this report are approximately $€ 2$ billion per week, a yearly total of about $€ 100$ billion, or $1 \%$ of aggregate GDP. In the UK, for example, youth unemployment cost the country f4.8bn in 2012 - more than the entire budget for educating 16- to 19-year-olds. This is in addition to the estimated f10.7bn in lost output for the same year (Tse and Esposito 2013).

There is a pressing need to combat youth unemployment and support targeted measures that aid young people in their transition from education to work. With a budget of €6 billion for the period 2014 - 2020, the Youth Employment Initiative aims to support NEETs in EU regions most affected by youth unemployment. 
One program called Youth Guarantee offered job training and apprenticeships to combat youth joblessness. The Youth Guarantee was considered as both a structural reform to drastically improve school-to-work transitions and a measure to immediately support jobs for young people. However, such policy "highlights a major disconnect: jobs are a consequence of economic growth. If there is no growth, there will be no new jobs. All the training in the world can't create jobs" (Tse and Esposito 2013).

The Eurozone has not grown in net terms since the first quarter of 2012, basically growth is stuck in neutral and affects unemployment. The analysis finds that the youth unemployment problem is multi-faceted in the bloc (B anerji et al., 2014):

The lack of growth plays an important role in explaining the upsurge in youth unemployment during the crisis. The sharp decline in economic activity - the largest such decline since the Great Depression-can on average explain about $50 \%$ of the increase in youth unemployment during the crisis (and even more-70 \% - in vulnerable euro area economies). In most countries, youth unemployment is almost three times more sensitive to growth than adult unemployment. This is possibly due to the concentration of youth employment in cyclically sensitive sectors of the economy (such as construction) and the generally more fragile employment conditions of younger workers (temporary and part-time contracts), which make them more susceptible to the effects of the recession.

Dual labor markets are characterized by a high share of temporary employment contracts with lower employment protection for workers who are on temporary contracts than for those on regular contracts. In general, the impact on labor market outcomes of employment protection legislation- laws governing the hiring and firing of employees-is found to be small and ambiguous, as it potentially lowers both the separation rate (by increasing the cost of firing), and also the employment rate (by increasing reluctance to hire workers in the first place). Also, duality could be more harmful for employment if combined with wage rigiditywhen hit by a negative shock, firms are unable to adjust wages and instead end up dismissing workers, particularly those on temporary contracts (i.e., mainly youth). For instance, labor market adjustments in Spain have mainly focused on shedding workers on temporary contracts.

Duality in a number of countries, particularly its unusual concentration among youth in Italy, Portugal, and Spain, creates unequal distribution of unemployment, hence such dual employment protection systems are the reflection of dysfunctional labor market institutions (Blanchard et al., 2013). 
With the continuing stagnation in Eurozone economies and inadequacy of new job creation, young people are the most disadvantaged due to lack of prior experience and skills. Entrepreneurship has been often cited as an option to counteract the obstacles young people face in the job market, while acting as a source of direct and indirect job creation.

Promoting youth entrepreneurship and making Europe a more entrepreneur-friendly environment has recently become one of the significant priorities in the EU policy agenda given its high potential for employment creation and ensuring sustainable growth (E urofound, 2015).

Much research suggests that the majority of entrepreneurs in the EU are male, wealthy, well-educated, white, and native-born, which is far from the ideal of inclusiveness. Figure 2 presents nascent entrepreneurship rates by gender for EU countries, which is defined as the proportion of the adult population who say that they are actively involved in setting up a business that they will own or co-own. The business must not have paid salaries, wages or any other payments to the owners for more than three months (OECD, 2014: 36).

Figure 2: EU N ascent Entrepreneurship Rates by Gender

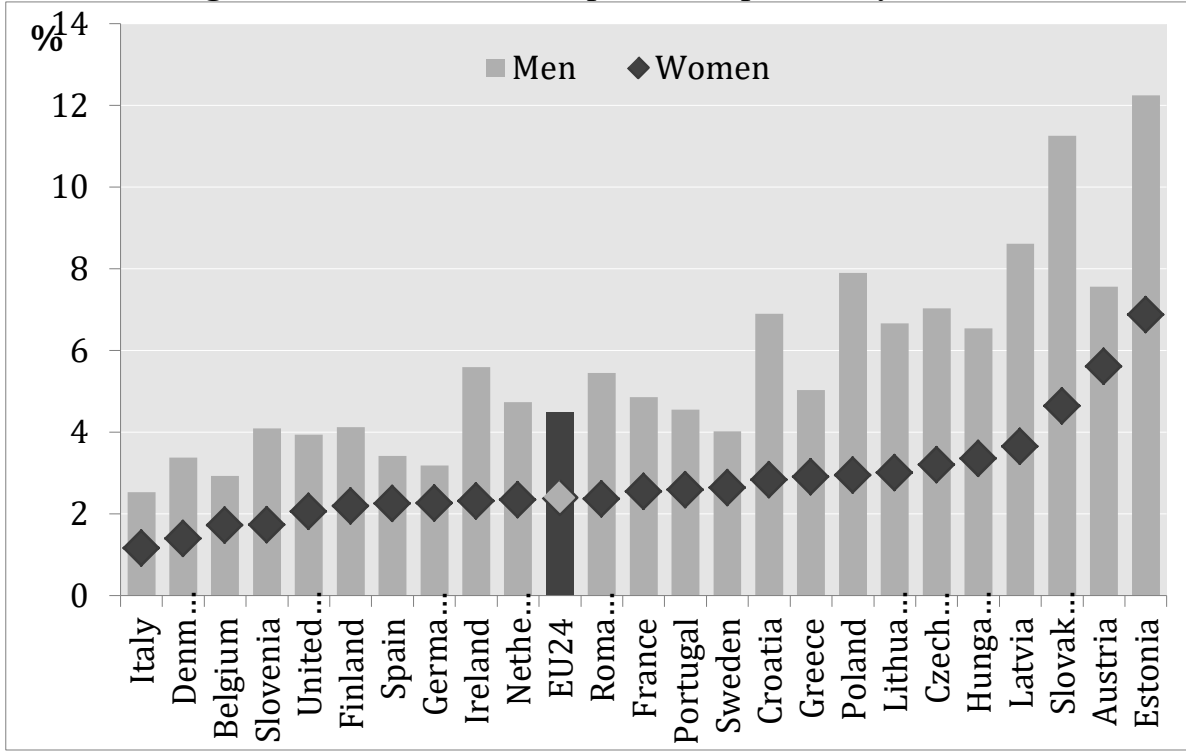

Notes: 1. The EU countries that participated in the Global Entrepreneurship M onitor survey over this period are: Austria, Belgium, Croatia, Czech Republic, Denmark, Estonia, Finland, France, Germany, Greece, Hungary, Ireland, Italy, Latvia, Lithuania, N etherlands, Poland, Portugal, Romania, Slovak Republic, Slovenia, Spain, Sweden and 
the United Kingdom. 2. Data presented in this figure are pooled data, combining the annual survey results over the 2008-12 period. A number of countries did not participate in the GEM surveys in every year but were included in the tables: A ustria (2012), C zech Republic (2011), Estonia (2012), Ireland (2008, 2010, 2011, 2012), Italy (2008, 2009, 2010, 2012), Lithuania (2011 and 2012), Poland (2011, 2012), Portugal (2010, 2011, 2012), Slovak Republic (2011 and 2012) and Sweden (2010, 2011, 2012). 3. The $\mathrm{N}$ ascent Entrepreneurship Rate is defined as the proportion of the adult population (age 18 to 64) that are actively involved in setting up a business they will own or co-own; this business has not paid salaries, wages or any other payments to the owners for more than three months.

At the same time, there is also an entrepreneurship quality gap affecting disadvantaged social groups; indicators of business turnover, income from selfemployment and business survival rates are all significantly lower for women, youth and immigrants compared with the rest of the population (European Commission, 2005).

The realities presented above testify to the fact that urgent precautions and actions must be taken in order to prevent the youth unemployment issue from becoming chronically unresolvable in the next generations. This study therefore presents findings and EU-wide recommendations relevant to this issue based on the user needs analysis conducted for the YEU (Y outh Enterprise and U nemployment) e-learning platform which was partially supported by the EU Commission between 2012-14. In the following sections, background information on online education, entrepreneurship, serious games and the Y EU Project is provided. Next the research methodology is outlined. Finally, research findings and recommendations with a view on contributing resolutions to the youth unemployment issue through the development of entrepreneurial skills, are presented.

\section{Online Education}

With the increasing pervasiveness of the internet and other digital technologies, online education (also referred to as e-learning) has become an indispensable tool for individuals and organizations alike. Online education includes a "wide set of application and processes including but not limited to web-based learning, virtual classrooms and digital collaboration" (KaplanLeiserson, 2002). While for individuals it is a relatively cheaper, flexible and accessible method for receiving education and training in a multitude of skill areas, it is widely used by organizations for employee training and knowledge management purposes.

As digital devices and software have diversified and become more prevalent, the use of online education tools has increasingly become an 
alternative to face to face learning especially for disadvantaged people who may not possess an immediate opportunity to receive education and training. The YEU e-learning platform was created with this fact in mind, so as to provide a free, comprehensive web based portal as an aid to enhance the entrepreneurial skills of the younger generation, with the final aim of contributing to job creation and tackling the unemployment issue in European countries.

\section{Entrepreneurship}

The concept of entrepreneurship as a constituent of business activity and job creation has been studied for more than a century in various disciplines, primarily in economics, followed by sociology, anthropology, history, ecology and psychology (A teljevic and Li 2009: 22). A basic definition of entrepreneurship and its core elements can be given as "the creation of an innovative organization for the purpose of gain or growth, under conditions of risk and/or uncertainty" (Dollinger, 2003).

According to Schumpeter (1934), from whom contemporary thinking on entrepreneurship largely derives, the entrepreneur is characterized as someone who innovates, at the level of firm organization, in product or service development, in extracting raw materials more efficiently, in rearranging modes of production, in developing novel networks or in opening up new market segments (Peters et al., 2009: 395). It can thus be deduced that entrepreneurial activity is a significant source for innovative business activities which generate job creation and added economic value (Van Praag and Versloot, 2007). Consequently, the enhancement of entrepreneurial skills by means of education and training especially among young adults is evoking interest at the EU policymaking level, as evidenced by the publication of a variety of analyses, reports and roadmaps pertinent to the issue; e.g. Addressing Y outh Unemployment in the EU (2015); The M issing Entrepreneurs (2014); Y outh Entrepreneurship in Europe: V alues, A ttitudes, Policies (2015).

\section{Serious Games}

Since the early 1970s, simulation games have been used to deliver diverse skills in higher education, including entrepreneurial, leadership skills and even economic forecasting (Faria, 2001). Dickinson and Faria (1995) report that over 200 business games were being used by nearly 9.000 teachers at over 1.700 colleges' business programs in the US. However, in Europe, the deployment rate of serious games in higher education continues to be quite low and 
educational benefits and practices on their use were rarely investigated and reported (B aalsrud $\mathrm{H}$ auge et al., 2013).

Although not widely utilized, certain number of high-level business games and simulations were used around universities and educational institutions in Europe. Gamlath (2009), with a game called SimV enture ${ }^{\mathrm{TM}}$, evaluated game performance to determine if performance was mainly due to skill or largely a matter of luck. In Greece, MAGEUR business game was played by students within an entrepreneurship training project which comprised seminars and case studies alongside the game (M antakas, 2010).

Co-funded by the Erasmus FEXI program, in eSG (entrepreneurship through Serious Games) project serious gaming was just one of various instructional strategies adopted. Obtained by surveying literature, entrepreneurs, students and teachers, main requirements -based on usability, pedagogy and entrepreneurship skills, for the entrepreneurship course and serious games were presented in an extensive study within eSG project (Bellotti et al., 2012). As a part of overall gamified learning process, and also the eSG project, mainly M.Sc. students, at the University of Genoa for Electronic Engineering B.Sc., participated in a study for the assessment of three games (Hot Shot Business, SimV enture ${ }^{T M}$ and Any Business) that address the field of entrepreneurship (H auge et al., 2013).

Serious games should be considered in fostering entrepreneurship of young people because games are effective tools for learning. They provide compelling contexts so that players can engage and practice challenges as the learning takes place (V an Eck, 2006). Entrepreneurship education should provide training in social skills, networking, creative problem solving, and opportunity seeking. According to Iten and Tetko (2014) "Serious gaming is regarded as a particularly active, problem-solving, situated and social form of learning with rapid and differentiated feedback that also promotes the enjoyment of learning."

The serious game developed during the Y ENTELS (Y oung Entrepreneurs elearning Suite) project is based on the scenario of starting a new DJ business as a young entrepreneur. The same game was later adopted by the Y EU project and translated into six more languages. Titled as "DJ Life", the objective of the game is to turn new DJ business into a success through making decisions relating to marketing, finance, and sales. The YEU Business Game, or DJ Life, is also an online learning exercise that draws together the information and lessons of prior Y EU e-learning courses, consolidates players' knowledge about the different aspects of running a business, builds confidence in analyzing the 
revenue-cost-profit economics of a business, helps players understand how the functional pieces of a business fit together, provides valuable practice in crafting profitable growth strategies, and sharpens the player's strategic business judgment. The game can be completed in approximately one hour, and depending on their success level, players can replay the game and test new found knowledge in the context of the game. As mentioned, the game is a part of an e-learning platform, in both YENTELS and YEU, and it is offered for free.

\section{YEU Project}

Co-financed by the European Commission under the Leonardo da V inci L ifelong Learning Program, Y outh Enterprise and U nemployment (Y EU) was a two-year (from November 2012 to November 2014) Transfer of Innovation project platform. YEU project aimed to improve the effectiveness of entrepreneurship training provided to young people living in those regions of Europe which have some of the highest levels of youth unemployment so as to enable them to consider starting their own businesses.

Y EU project was a partnership between business intermediary organizations (such as Chambers of Commerce), educational establishments (U niversities and institutes) and young people's organizations (NGOs and associations). In general, the project intended to provide entrepreneurial training which is accessible to all young people and which will be particularly targeted at those countries having some of the highest rates of youth unemployment in Europe.

Seven partner countries (UK, Bulgaria, Italy, Slovenia, Poland, Portugal and Turkey) collaborated in YEU to improve the existing YENTELS (Y oung Entrepreneurs E-Learning Suite) system by incorporating social media technologies, video clips of young people's experiences in running a business, creating a "lite" version of the training for m-learning environments and by making some improvements to the original Y ENTELS business game based on suggestions made by users during the past few years.

The YEU project was specifically targeted at those with few or no formal qualifications (i.e. the NEET group), those unemployed $(20 \%+$ of all young people across Europe) and groups (i.e. young people) facing socio-economic disadvantage in the labor market because of their age and lack of experience and confidence to set up their own business.

The YEU project was built on the findings and conclusions of another Leonardo funded online learning project: YENTELS. The most relevant issues across European countries with respect to the Y EU project were as follows: 
- Higher education institutions should integrate entrepreneurship across different subjects and courses, notably within scientific and technical studies.

- $\quad$ Public authority support is needed to provide high-level training and to develop networks that can share good practice. A more dynamic partnership is required between the business world and education professionals, which is heavily focused on the provision of young people's education.

- Training material for the YENTELS project should be structured to mirror the levels of apprenticeship to ensure more relevance and adequate assimilation of the content by students.

When completed in 2014, Y EU e-learning platform provided tools for elearning training and resources on entrepreneurship, all free and available in seven languages including:

- $\quad \mathrm{N}$ ine e-learning modules on key skills needed to start and run a business.

- A serious game based around starting up a new business.

- A set of resources providing links to key information (knowledge base).

\section{Methodology}

The aim of the user needs analysis research was to help clarify the needs of the users, stakeholders and trainers, in order to provide the YEU platform with e-learning materials that are fit for purpose. The content of the initial YEU online course structure also incorporated and developed existing YENTELS course materials, whilst using the research findings to tailor its design and marketing to ensure they are packaged in a manner that is most suitable for the target audience of young people. The findings of the research were also used to influence other technical design considerations of the portal and business game, and assess the appropriateness of different types of emerging e-learning technologies for the target group in order to aid its development. For the purpose of this study, the research results are used to propose a multifaceted approach to the development of young people's entrepreneurial skills as a solution alternative to the youth unemployment issue in critical European countries. 
Research M ethodology and Main Q uestions

The target research group included a specific focus on young people not in education or employment (NEET), young adults in formal education and those employed by SMEs and creative or IT businesses.

Birmingham Ormiston Academy ( $B O A)$, with the support of the other partners, provided the research framework and methodology which enabled the partners to carry out the research with young unemployed/employed people, young people in education, and with other stakeholders such as entrepreneurs, policy makers and employers.

Table 1: Research M ethods for Y EU U ser N eeds A nalysis

\begin{tabular}{|l|l|l|l|}
\hline \multicolumn{2}{|l|}{ Action/Primary Research } & Desk/Secondary Research \\
\hline Quantitative & Qualitative & Quantitative & Qualitative \\
\hline Questionnaire & $\begin{array}{l}\text { One-to-one } \\
\text { interview }\end{array}$ & Surveys & B ooks \\
\hline Surveys & $\begin{array}{l}\text { Focus } \\
\text { groups }\end{array}$ & $\begin{array}{l}\text { Questionnaire } \\
\text { results }\end{array}$ & Internet articles \\
\hline & $\begin{array}{l}\text { Case } \\
\text { studies } \\
\end{array}$ & $\begin{array}{l}\text { Third party } \\
\text { database } \\
\text { interviews }\end{array}$ & $\begin{array}{l}\text { Periodicals; } \\
\text { Newspapers, M agazines }\end{array}$ \\
\hline & Observation & Documentaries and B iographies \\
\hline & Testing & & Third party case studies \\
\hline & & & A rchives, including video \\
\hline & & & Other Library resources; e.g. M icrofiche \\
\hline & & & National Legislation and regulations \\
\hline
\end{tabular}

The research was carried out in Bulgaria, Italy, the UK, Poland, Slovenia, Portugal and Turkey. Table 1 above provides details of the types of primary and secondary research methods used. D esk research was considered as a secondary method that delivered national level data from all partners' government agencies and also complemented a scientific approach to the problem at hand, 
given the limited resources that could be dedicated by all partner institutions involved.

The user needs analysis was implemented in three research cycles. A combination of desk research of existing literature and a range of primary research mechanisms - including one-to-one discussions / interviews, social media (i.e. Facebook), printed questionnaires and workshops were used. To help obtain higher quality results, many of the surveys were carried out by faceto-face interviews. The primary research universe comprised both representative groups and the young people themselves.

A draft questionnaire was prepared by $B O A$, then revised and finalized in line with the contribution of the partners. Two separate questionnaires, provided in Appendices 1 and 2, were developed for stakeholders and young people. Some open-ended questions were included in the survey for qualitative analysis in addition to close-ended questions. The partners translated both questionnaires into their respective languages and then prepared a summary report of the responses. The data collected by the partners was merged in order to devise a common roadmap.

This research was primarily intended to help the partners identify skills gaps for young people in order to determine the most effective training options and modules needed to overcome these gaps in knowledge. The user needs analysis was not only indispensable for effectively achieving the project outcomes, but also in providing a valuable contribution to the development of young people's entrepreneurial skills, and policy making with respect to youth unemployment.

The key questions that the research aimed to answer were as follows:

- What local, regional and national opportunities/strategies have been put in place to respond to the high levels of youth unemployment?

- What support is available for young people wanting to set-up a business?

- What challenges do young people face when looking for a job or when starting a business?

- What factors have led to such high levels of youth unemployment?

- What do we need to do in order to improve the employability of our youth?

- What resources and tools are there available in assisting young to startup and/or maintain a business in your country? 
- Can entrepreneurship contribute to high levels of youth employment?

o If it can, what can we do to support young people in becoming successful entrepreneurs?

Partners U ser Research M etrics and Sample U niverse

The primary target group were NEETs with a minimum of 25 participants per partner country, whereas the secondary target groups were identified as:

- ICT, New media and trades based industries - minimum of 10 per partner country

- Y oung people employed in SM Es - minimum of 10 per partner country

- Young people in formal education - minimum of 10 per partner country

Partners also had to ensure that as a minimum they carried out consultations with at least 10 of the following stakeholder groups per partner country:

- Y oung People Support Organisations

- Government Organisations

- Educational Establishments

- Employers

- Business Supports

- Employment/U nemployment Specialists

- Careers A dvice

\section{Findings}

The following tables provide an analysis of the numbers of respondents who were sampled. 
Table 2: Qualitative Primary M ethod

\begin{tabular}{|c|c|c|c|c|c|}
\hline Partner & Stakeholders & NEET & $\mathrm{ICT}^{*}$ & $\begin{array}{c}\text { Young } \\
\text { People } \\
\text { employed in } \\
\text { SMEs }\end{array}$ & $\begin{array}{c}\text { Young } \\
\text { People in } \\
\text { formal } \\
\text { education }\end{array}$ \\
\hline CWCC & 12 & 14 & & 19 & \\
\hline DemoCentre & 14 & & 5 & & 20 \\
\hline $\mathrm{BOA}$ & 5 & & & 1 & 16 \\
\hline CPU & 10 & & & & \\
\hline WSEI & 10 & & & 10 & \\
\hline Y editepe & 52 & & & & \\
\hline Edit $V$ alue & 6 & & 1 & & \\
\hline Bulgaria** & 9 & & & & \\
\hline Total & $\underline{118}$ & 14 & $\underline{6}$ & 30 & $\underline{36}$ \\
\hline
\end{tabular}

$*$ N ew media and trades based industries

** A ggregate numbers for Start U $p$ and V irtech

Table 3: Quantitative Primary M ethod

\begin{tabular}{|l|c|c|c|c|c|}
\hline \multicolumn{1}{|c|}{ Partner } & Stakeholders & NEET & ICT* & $\begin{array}{c}\text { Young } \\
\text { People } \\
\text { employed in } \\
\text { SMEs }\end{array}$ & $\begin{array}{c}\text { Young } \\
\text { People in } \\
\text { formal } \\
\text { education }\end{array}$ \\
\hline CW CC & 15 & 14 & 13 & 19 & 19 \\
\hline DemoCentre & & & & & 50 \\
\hline BOA & & 44 & & 72 & 270 \\
\hline CPU & & & & & 136 \\
\hline W SEI & & 32 & 2 & & 97 \\
\hline Y editepe & & 28 & & 19 & 12 \\
\hline E dit Value & & & & & 93 \\
\hline B ulgaria** & & $\underline{\mathbf{1 1 8}}$ & $\underline{\mathbf{1 5}}$ & $\underline{\mathbf{1 1 0}}$ & $\underline{\mathbf{6 8 3}}$ \\
\hline Total & & & & & 6 \\
\hline
\end{tabular}

* N ew media and trades based industries

** A ggregate numbers for Start U $p$ and V irtech 
Demographics

$34 \%$ of respondents were male and $66 \%$ were female. The breakdown of respondents by age can be seen in Figure 3 below.

Figure 3: Respondents by Age

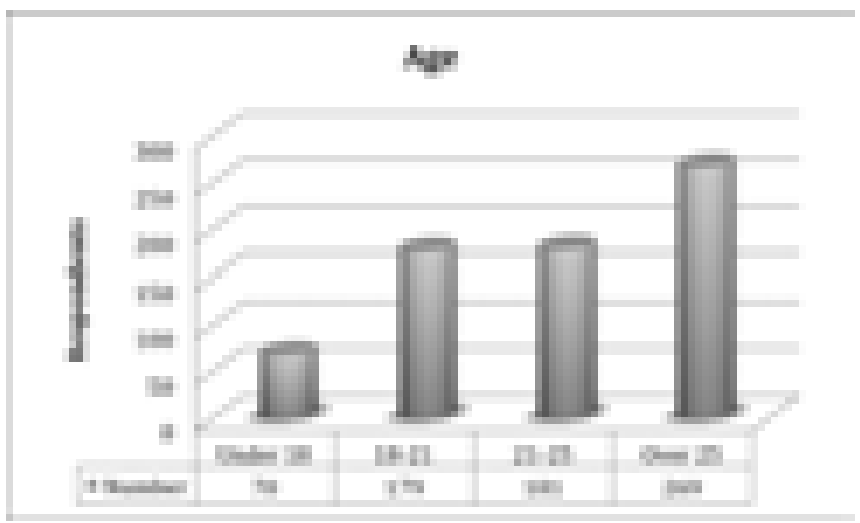

Figure 4 below demonstrates respondents' status based on their education, employment and entrepreneurship. NEET status is al so included in the data.

Figure 4: Respondents by Status

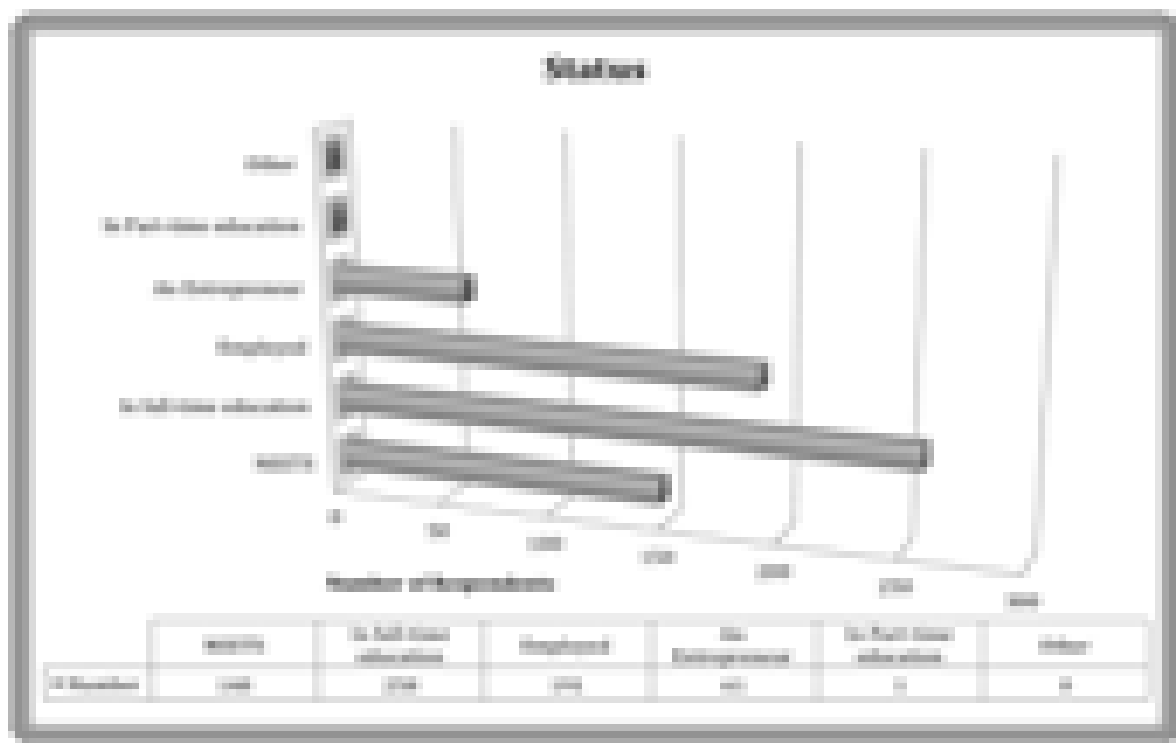


Partners' Reports on U ser-needs Research M etrics and Results

The findings in this study are based on the results obtained from a user needs analysis for a projected e-learning platform. The collected data was primarily used to pinpoint user needs in order to develop and then modify the YEU online platform in accordance with the project outcomes. On the other hand, the analysis revealed crucial issues and resolution suggestions with respect to youth entrepreneurship, unemployment and policy making at various public levels. The results presented below reflect the experiences of partners during primary investigations along with research metrics:

- In one-to-one interviews, CWCC, Coventry-Warwickshire Chamber of Commerce, engaged 19 young people involved in training, and an additional 13 people from the NEET category. A further 11 NEETS were engaged through a workshop.

From stakeholders, 2 job shop staff were interviewed, with 4 other stakeholders via one-to-one meetings, and an additional 8 via a Board Meeting. Shop vouchers were provided to those young people who carried out an interview.

- Democentre, an incubator and university spin-off, engaged approximately 40 young people in their user needs research and relied on their close associations with the province of M odena and its universities of 'M odena' and 'Reggio Emilia' alongside other universities including Bologna and Parma. They found that youth unemployment is a very popular and current topic in Italy and it was not difficult to obtain responses to their questions.

- BOA contacted their students (aged 14 - 19) and various other groups of young people, and obtained approximately 270 responses through quantitative and qualitative research methods. Since they are an academy (school), they have excellent links with several stakeholders who work with young people and support them in the world of work and starting up a business.

- CPU, a university institute, used the innovative approach of contacting their colleagues' sons and daughters via Facebook to gain their views on youth and unemployment and received 259 replies.

- As a business school, WSEI asked their lecturers to talk to students about the project during lessons after which students completed the written questionnaires. As a result, they gained responses from 100 young people. 
They used their contact network with local and partner institutions to gain feedback from 10 stakeholders.

- Y editepe U niversity Faculty of Commerce received 46 completed written and on-line questionnaires from the NEET group, in addition to 5 interviews with young people and 3 interviews with entrepreneurs/ employers.

- Edit V alue, a university spin-off and incubator, used interviews and written questionnaires to gain responses from 53 young people and 7 stakeholders. They found that the survey respondents were receptive to the project concept and feedback indicated the project brochure was very useful in explaining this.

- Start-up Bulgaria, a youth association, and V irtech, an SME in the IT sector, used a combination of 9 interviews with stakeholders which included various organizations and personalities, and 93 online and offline questionnaires distributed through their communication channels and various events they organized.

\section{Employment}

A large percentage of young people surveyed had no work experience, even voluntary work - leading to inexperienced and unskilled graduates and young people. In terms of young people's experiences and expectations of employment, the quantitative research revealed that the vast majority of respondents planned to continue in training or education, or acquire more skills (Figure 5). 
Figure 5: Respondents plans for future

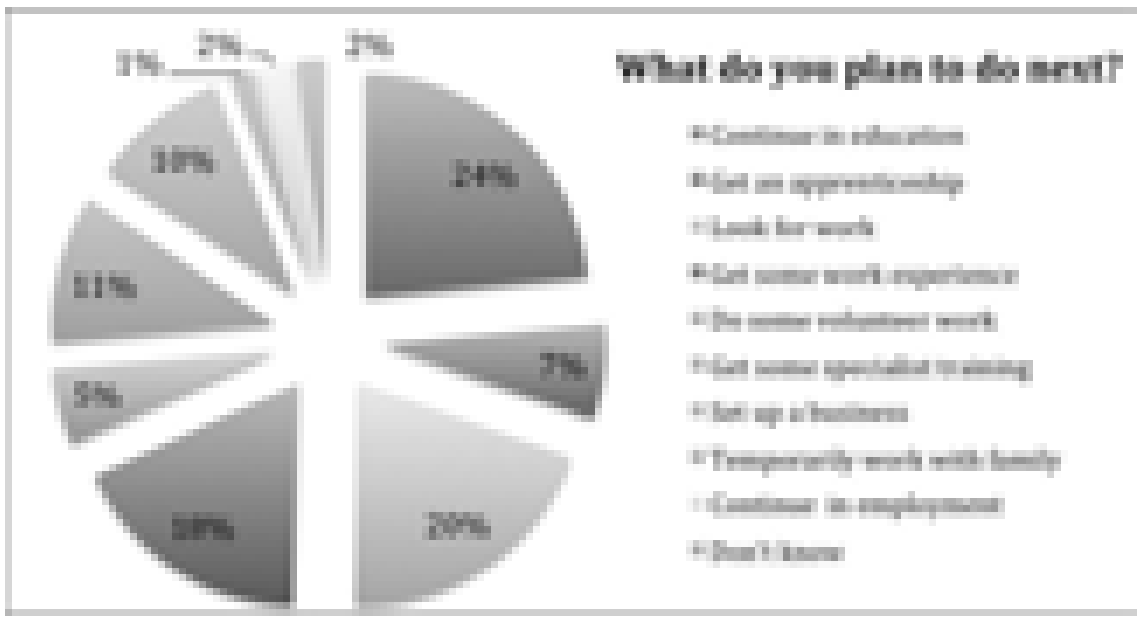

In the rural areas (in most partner countries), young people have the desire to set-up their own businesses but are encouraged to advance to university and are not given other options. In Poland, the situation is different, as young people are advised to follow a vocational route and start work as soon as possible. Moreover, a significant majority (63\%) of these respondents had no opportunities for vocational study during their schooling experience.

\section{Pre-employment Skills}

A large proportion of young people felt that they received inadequate careers advice at school, which led to unrealistic expectations of the job market. They also reported not knowing how to prepare for or perform at interviews, and lacked the necessary knowledge of interview techniques, and communication skills to perform well. Most young people surveyed did not know what a good CV looks like, and those who have one rarely keep it up-todate.

The vast majority, $87 \%$ of respondents, commented that they have IT skills. Interestingly, the stats show that not all of them utilised these skills to create a CV , as $64 \%$ of $18+$ year olds reported having an up to date CV. Lacking IT skills or varying level of access to IT resources and the Internet often relate to digital divide within the country, while this topic is beyond the scope of the research. 
Following on from this, a significant majority (67\%) of respondents reported not receiving any careers advice whatsoever.

\section{Business Start-Up Issues}

Despite findings of the research indicate that many Higher Education institutions have set-up business incubation units to support enterprising graduates, the quantitative research al so showed that a large percentage of young people would like to set-up a business, but do not know how to go about it In particular, $68 \%$ of respondents (in education, employed or NEET) have thought about setting up their own businesses, but over half reported not knowing where to get help on how to set up and run a business.

$68 \%$ of respondents (age 18+) also thought that setting up a business was either difficult or very difficult, or did not have an idea:

Figure 6: Ease of setting up a business

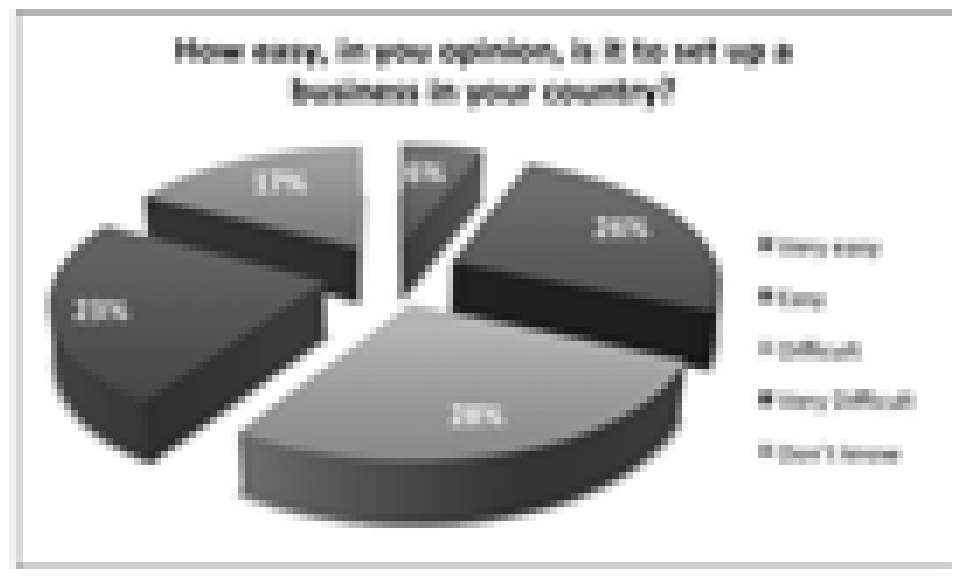

Findings of Qualitative Research

Qualitative research findings related to employment and start-up issues are described below. First, findings about employers are reported followed by the case of graduates and finally business start-up issues are reveal ed. 


\section{Employment}

In terms of young people's and employers' experiences and expectations, the qualitative research on employers indicated that:

- Graduates and young people's skill levels do not meet the needs of their business, particularly in the area of 'communication and interpersonal skills.'

- The current economic climate does not stimulate young people to view independent entrepreneurship as a viable career path. The lack of initial funding is a main barrier to starting a business.

A nd for the graduates:

- Feel cheated by their qualifications. They are seen as a risk by employers, who have little confidence in the skills of new graduates and instead opt to retain and retrain their existing workforce.

- R esearch from most of the partner countries shows that young people don't want to do the jobs currently available on the market and find them unattractive. They feel that applying for an unattractive job defeats the entire purpose of going to university.

- $\quad$ Y oung people have unrealistic expectations of entering the job market.

\section{Business Start-Up Issues}

The qualitative research on business start-up issues shows that:

- $\quad$ Y oung people with entrepreneurial aspirations from both urban and nonurban areas felt they were signposted towards attending university, despite this not being their preferred development route. Those with poorer grades were shepherded into manual jobs.

- A greater need for vocational study was expressed, especially for those engaged in the Arts, with a specific focus on incorporating a business element in their chosen area of study.

- The business training currently available needs to be more vocation-based: Young people feel they gain more in business practice and application when learning is experiential and contextualised, rather than through an academic approach. For example: writing a business plan can easily be done in a classroom, however, putting it into practice and sticking to it in the world of business is quite another subject. 
- There is a growing demand for freelancers and self-employed professionals in ICT and the Arts.

- $\quad$ Current business training and support only partially meets young people's needs, particularly if they want to set up their own business.

\section{Conclusions of Research Study}

The research carried out by the YEU project partners provided a Europewide Training Needs Analysis Research Report, which highlights the main trends and findings as follows.

The European Policy Level

- Governments are investing a lot into entrepreneurship and view this as having a role in dealing with high youth unemployment figures.

- $\quad$ European leaders are implementing new schemes aimed at increasing work opportunities for young people and setting up initiatives to encourage entrepreneurship and boost youth employment. In J une 2013, they pledged 6 billion euros over two years to ensure job creation, training, and apprenticeships for young people.

- $\quad$ The support structures do not seem to be achieving the intended results.

- A key European priority is to reduce NEET numbers. However, attempts to achieve this have been widely criticized since the statistics show they are failing.

Young P eople's Employment

- $\quad$ Y outh unemployment is in a dire state across Europe. As a result, young people who are academic are continuing in education as long as they can.

- U niversity graduates and young people are often branded by employers as lacking the essential skills needed for work. It is argued that education establishments sometimes concentrate too much on students passing exams rather than equipping them with essential 'life skills'. Indeed, the research showed that there is a large percentage of unskilled graduates, and this is certainly the business world's perception.

- Following on from this point, graduates feel massively cheated by their higher education qualifications as employers have no confidence in graduate employees. This is leading to a high level of emigration as graduates see no other option of finding work. 
- Opportunities for young people are changing. However, this view is, unfortunately not shared between much of the NEET population.

- There is a need to develop essential pre-employment training and employability skills and improve the quality of support available to young people wanting to enter the job market.

- A high number of young people lack the skills and do not have the experience to embark on a successful career.

- Y oung people don't seem to be attracted to the vast majority of jobs on the market, for example jobs that rely on physical work, those that aren't considered reputable and less skilled employment in relation to their education.

- Those young people who are not so academic, lack the correct guidance and support to allow them to make the right career choices. Almost $98 \%$ of young people sampled in this research are computer literate, but a large percentage of those do not know how to effectively utilise these skills in order to secure employment, (e.g. to create a CV ).

Business Start-Up

- A vast majority of young people would like to start a business but do not know how to go about it or even where to start.

- Young people are put off by the processes and procedures one has to go through when starting a business.

- In most of the partner countries, young people are not aware of the support that is available to them. As such, young people look to or depend on their families to provide financial support when setting-up a business.

- Entrepreneurship is seen as an option to very few involved in the research.

- A lot more needs to be done to support educational institutions in encouraging, helping, supporting and guiding potential entrepreneurs.

- There are several initiatives and intermediary organisations out there to support young people into business, but their target audiences are unaware of their existence.

For national level strategy, qualitative findings also emphasized that more vocational-based business training, with a focus on business set-up is needed. A practical level of business acumen is even more important for recent graduates who go on to work in the sectors where they will often be self-employed, have 
to manage their own tax-returns and accounts, learn how to be competitive in the business world, and seek out markets to work in.

Based on responses from the young people in Turkey - often stating that they generally do not feel that they have had a useful and effective work experience during their education- policies or industry-wide regulations can be revamped to support employment during education, especially at the internship level or as part-time employment.

Further recommendations for the YEU project were also presented as a result of user needs analysis, such as developing a user-friendly resource for young people and ensuring that it is fit-for-purpose, while making certain that on-line resources in YEU platform should incorporate materials that improve employability; e.g. advice and guidance on interview techniques, communication skills, business etiquette, personal development, adaptable CV s. 


\section{References:}

A teljevic, J. and Li, L. (2009) "Tourism Entrepreneurship: Concepts and Issues", in Jovo Ateljevic and Stephen J. Page (ed.s.), Tourism and Entrepreneurship: International Perspectives, (Oxford: Butterworth Heinemann), pp. 9-32.

Bellotti, F., B erta, R., De Gloria, A., Lavagnino, E., Dagnino, F. M., Ott, M., Romero, M,. Usart, M. and M ayer, I.S. (2012) "Designing a Course for Stimulating Entrepreneurship in Higher Education through Serious Games", Procedia Computer Science, 15: 174-186.

Blanchard, O., Jaumotte, F. and Loungani, P. (2013) "Labor M arket Policies and IM F A dvice in A dvanced Economies During the Great R ecession", IM F Staff Discussion Note 13/02, International M onetary Fund, Washington DC.

Banerji A, Saksonovs S., Lin H., and Blavy, R. (2014) "Y outh Unemployment in Advanced Economies in Europe: Searching for Solutions", IMF Staff Discussion Note 14/12, European Department and Research Department, International M onetary Fund, W ashington DC.

Dickinson, J. R. and Faria, A. J. (1995) "Simulation Gaming for Sales M anagement Training and a Demonstration", in Danny Saunders (ed.), The Simulation and Gaming Workbook Volume 3: Games and Simulations for Business, (L ondon: Kogan Page) pp. 99-109.

Dollinger, M.J. (2003) Entrepreneurship: Strategies and Resources, (Upper Saddle River: Prentice Hall).

Eurofound (2015) "Y outh Entrepreneurship in Europe: Values, Attitudes, Policies", Publications Office of the European U nion, L uxembourg.

European Commission (2005) "Factors of business success survey", Eurostat. European Commission "(2016) "Youth Employment", http://ec.europa.eu/eurostat/documents/2995521/7412086/3-31052016-A PEN.pdf/, (08 July 2016).

Faria, A. J. (2001) "The Changing Nature of Business Simulation / Gaming Research: A Brief History", Simulation and Gaming: An Interdisciplinary J ournal of Theory, Practice and Research, 32: 97-110.

Gamlath, S.L. (2009) "Field Testing Two Simulation Games: Do W inners W in Consistently?", On the Horizon, 17(4): 388-396. 
Gosh, P. (2013) "A rrivederci Roma: Italians Desperate to Emigrate, as Y ouths Staggered by $40 \%$ Joblessness", November 21, 2013, $<$ <ttp://www.ibtimes.com/arrivederci-roma-italians-desperate-emigrateyouths-staggered-40-joblessness-1479332> (11 A pril 2015)

Hauge, J. B., F. B ellotti, R. B erta, M. B. Carvalho, A. De Gloria, E. Lavagnino, R. Nadolski and M. Ott, (2013) "Field Assessment of Serious Games for Entrepreneurship in Higher Education", Journal of Convergence Information Technology, 8(13): 1-12.

Hauge, J. B., Bellotti F., Nadolski R., Kickmeier-Rust M., Berta R. and Carvalho M.B. (2013) "Deploying Serious Games for Management in Higher Education: L essons L earned and Good Practices", paper presented at The 7th European Conference on Games B ased Learning, Porto, Portugal, 340 ctober.

Iten, N . and Petko, D. (2014) "Learning with Serious Games: Is Fun Playing the Game a Predictor of Learning Success?", British J ournal of Educational Technology, doi: 10.1111/bjet.12226

Kaplan-Leiserson, E. (2002) "E-learning glossary", </http://www.learningcircuits.org/glossary.html> in Cerdán-Chiscano, M. and Jiménez-Zarco, A. I. (2014) "E-Learning and Entrepreneurship: Boosting Spin-Offs' Success Through a Process of Acceleration", eLC Research Paper Series, 9: 45-55.

M antakas, M. (2010) “Using a M anagement Game within an Entrepreneurship Training Project for the Students of an Informatics and Telecommunications Degree", Proceedings of the SGEED-2010 Conference Serious Games, Education \& Economic Development, Ioannina, Greece, 7-9 July. $<$ http://www.scribd.com/doc/218665817/12-M antakas-B usinessGame\#scribd>.

OECD/The European Commission (2014), The M issing Entrepreneurs: Policies for Inclusive Entrepreneurship in Europe, OECD Publishing. <http://dx.doi.org/10.1787/9789264213593-en> , (22 D ecember 2014).

Peters, M., Frehse, J. and Buhalis D. (2009) "The Importance of Lifestyle Entrepreneurship: A Conceptual Study of the Tourism Industry", Pasos, 7(2): 393-405.

Sharma, R., Ekundayo, M. S. and N eg. E. (2009) "Beyond The Digital Divide: Policy Analysis for Knowledge Societies", Journal of Knowledge Management, 13(5): 373-386. 
Schumpeter, J.A. (1934) The Theory of E conomic Development, (New York: Oxford U niv. Press).

Tse, T. and Esposito, M . (2013) "Y outh U nemployment Could W reck Europe's Economic Recovery: Training Schemes Are Laudable, but there is a Disconnect B etween W hat Y oung People L earn and W hat E mployers W ant", November 14, 2013, http://www.theguardian.com/commentisfree/2013/nov/ 14/youth-unemployment-wreck-europe-economic-recovery, (9 February 2015).

Van Eck, R. (2006) "Digital Game-Based Learning: It's Not Just the Digital Natives Who A re Restless", EDU CAUSE Review, 41(2): 16-30.

Van Praag, C. M. and Versloot, P. H. (2007) "What is the Value of Entrepreneurship? A Review of Recent Research", Small Business Economics, 29(4): 351-382. 


\section{Appendix One: Youth Questionnaire}

\section{General info}

1. Age:

- Under 18

- $18-21$

- $21-25$

- Over 25

2. Are you:

- Male

- Female

3. Do you live in:

- A major city

- A small city

- A town

- A village

4. A re you:

- Renting privately

- Living in social housing - Council

- Living with parents

- Paying a mortgage

- Other (specify)

5. A re you a carer?

- Yes

- No

6. Do you have any dependants?

- 0

- 1

- 2

- 3 or more

7. Do you have any disability?

- Yes

- No 
8. A re you:

- $\quad$ ot in employment, education or training

- In full-time education

- Employed

- An Entrepreneur

9. What social media platforms do you use?

- Facebook

- Skype

- Twitter

- YouTube

- MySpace

- Linkedln

- Other (specify)

- None

\section{Education}

10. Did you have opportunities for vocational (learn a trade) study during your school experience?

- Yes

- No

11. What is the highest level of education you possess (EQF - European Qualification Framework)?

- No formal education

- Level 1

- Level 2

- Level 3

- Level 4

- Level 5

- Level 6

- Level 7

- Level 8

- $\quad$ Other (specify)

12. What do you plan to do next?

- Continue in education

- Get an apprenticeship

- Look for work

- Get some work experience 
- Do some volunteer work

- Get some specialist training

- Set-up a business

- Temporarily work with family

- Don't know

13. Do you possess any IT skills?

- Yes

- No

14. Do you have access to a computer at home?

- Yes

- No

15. A re you confident in using a computer?

- Yes

- No

16. Which of the following can you do?

- Create a word processing document

- $\quad$ set-up a spreadsheet database

- Digital imaging and manipulation

- Use e-mail

- Use specialist software (please specify)

- None of the above

\section{Work and training}

17. Have you ever been in employment?

- Yes

- No

18. Have you ever had any unpaid/voluntary work?

- Yes

- No

19. A re you actively seeking employment?

- Yes

- No 
20. What resource do you use for looking for work?

- Jobcentre

- Newspapers

- Internet

- Personal contact / networking

- Cold calling

- Friends and family

- Other (specify):

21. Have you ever received any careers advice?

- Yes

- No

22. Have you considered apprenticeships?

- Yes

- No

23. Do you have an up-to-date CV?

- Yes

- No

24. What sector is your ideal job within?

- IT

- New Media

- The Arts i.e Digital A rts, Performing A rts, C reative A rts

- Administration

- Public service

- Retail

- Health and social care

- Construction

- M anufacturing

- Hospitality - travel and tourism

- Other (specify)

25. What barriers prevent you from getting your ideal job?

- Insufficient education

- Lack of jobs available

- Specific training requirements

- insufficient experience 


\section{Entrepreneurship}

26. Do you have a bank account?

- Yes

- No

27. Do you know anyone who has a business?

- Yes

- No

28. Have you ever thought about setting up a business?

- Yes

- No

29. Do you have a business idea?

- Yes

- No

30. Do you know where to go to get help on how to set-up a business?

- Yes

- No

31. Do you think that one would benefit from having a business mentor?

- Yes

- No

32. What barriers do you think you would face when starting a business?

- Leadership and management skills

- Funding/money

- Security

- Responsibility

- Business advice

- W riting a business plan

- Understanding taxes

- Employing people

- Managing people

- Other (specify): 
33. Do you know how to do the following?

- Write a business plan

- Do a cash flow projection

- O pen a business account

- Raise money

- Do the taxes

34. How easy, in your opinion, is it to set-up a business in your country?

- Very easy

- Easy

- Difficult

- Very difficult

- Don't know 


\section{Appendix Two - Stakeholder Aide Memoire}

To improve the effectiveness of entrepreneurship training to young people living in those regions of Europe which have some of the highest levels of youth unemployment. This way they will be able to consider starting their own businesses as an alternative to unemployment or unsuccessfully applying for the few jobs available.

\section{Questions for Young People}

? Name

? What is your ideal job?

?] Do you have an idea that you'd like to turn into reality? If so, what is it?

? How are you going to make it happen?

? How important is it to have an up-to-date CV?

? Do you feel you had good and meaningful work experience at school?

? Have you received any careers advice? If so, who from?

? How do you think you would benefit from careers advice?

?] Tell us about interview

?? Is there something you'd like to change about society? How would you do it?

?? W What do you think you'll/would you like to be doing in 10 years' time?

?]? In your opinion, what is enterprise? [i.e. "Enterprise is......... .]

\section{Questions for Entrepreneurs}

1. Name of organisation

2. Description of business

3. How have you turned your ideas into reality?

4. What does it take to be a successful entrepreneur?

5. Was it difficult to put together a business plan?

6. Where did you get the capital to fund your business?

7. Would you ever work for someone else?

8. Would you see yourself doing something for free?

9. What challenges have you faced when running your business?

10. Do you have a mentor? If no, what difference would having a mentor bring to your business?

11. What makes a business grow and last?

12. What business training would you require? 
13. What advice would you give to young people with good ideas?

14. Have you noticed any current trends in enterprise in this country? A nd what do you think is the future of enterprise? [i.e. young people/environmental issues etc.]

15. Is there such thing as an enterprising culture? If so, what is it?

16. In your opinion what is enterprise? [i.e. "Enterprise is......... . ]

\section{Questions for Policy Makers}

1. Name of organisation

2. Description of organisation

3. What support do you offer to young entrepreneurs?

4. Why encourage young people to be enterprising?

5. Have you noticed any current trends in enterprise in this country? A nd what do you think is the future of enterprise in UK?

6. Is there such thing as an enterprising culture? If so, what is it?

7. In your opinion what is enterprise? [i.e. "Enterprise is......... . ]

\section{Questions for Employers}

1. Name of organisation

2. Description of organisation

3. Why is there an increase in the levels of youth unemployment?

4. What needs to happen to improve young people's employability?

5. What advice would you give to young people to make them more employable?

6. Why encourage young people to work?

7. What are the needs of the labour market?

8. What will help young people to get into work?

9. A re young people prepared for the workplace?

10. Would you say that you have an ageing workforce?

11. Have you noticed any current trends in youth employment/unemployment in this country? A nd what do you think is the future of youth employment in UK?

12. Is there such thing as an enterprising culture? If so, what is it?

13. In your opinion what is enterprise? [i.e. "Enterprise is......... . ] 